\title{
SOME QUESTIONS OF METHODOLOGY FOR CONDUCTING TESTS OF RADIATION PROTECTION OF ARMORED OBJECTS
}

\author{
A. N. Dovbnya ${ }^{1}$, V.P.Starenky ${ }^{2 *}$ I. G. Goncharov ${ }^{1}$, I. Y. Cherniavskiy ${ }^{3}$, \\ O. A. Anashkin ${ }^{4}$, V.O. Vlasenko ${ }^{4}, K . S$. Ovcharenko ${ }^{2}$ \\ ${ }^{1}$ National Science Center "Kharkiv Institute of Physics and Technology", 61108 Kharkiv, Ukraine; \\ ${ }^{2}$ S.P. Grigoriev Institute for Medical Radiology of National Academy of Medical Science of Ukraine, Kharkiv, Ukraine; \\ ${ }^{3}$ Military Institute of Tank Troops of the National Technical University "KhPI", Kharkiv, Ukraine; \\ ${ }^{4}$ Kharkiv Morozov Machine Building Design Bureau, Kharkiv, Ukraine
}

(Received October 17, 2018)

The results of approbation of the methodology for laboratory testing a materials for armored objects ${ }^{6}$ radiation protection by determining their half-value layer for nuclear radiations, which are typical for the main situations of the radiation factor effect in modern conditions, are presented.

PACS: 06.60Wa, 87.50.Pr, 06.70.Ep

\section{INTRODUCTION}

Using composite (layered) materials with a low ionizing radiation-transmission factor, in particular hydrogenous polymers with the addition of boron or lithium is the main direction for radiation protection (RP) increasing [1]. According to the cost-effectiveness criterion, for improving a $\mathrm{RP}$ of some types of vehicles, an additional protection elements manufactured using specific materials (borated polyethylene with polyisobutylene and with admixtures of bromine and lead compound) as the lining and applique are used instead homogeneous materials. For increasing attenuation degree of cumulative dose corresponded to gamma neutron penetrating radiation to $3 . .3 .5$ times, it is necessary in average $300 \ldots 400 \mathrm{~kg}$ of RP material, which leads to essential worsening the combat vehicle tactical performance specifications. At the same time mass-dimensional parameters of combat vehicles' $\mathrm{RP}$ (connected with protective properties of materials proposed by manufacturers) depend on energy spectrum of effecting momentary radiation, and as literature analysis show [2-4] on neutron spectrum (type of nuclear charge), and on spectrum of capture (secondary) gamma rays.

Certainly, an experimental estimating the protective properties of RP materials must be carried out using the most dangerous (hard) radiation component, in order to determine the compliance of the technical protective characteristics of the test sample with the requirements specified in regulatory documents. In practice, this problem, as well as a comprehensive estimation of a vehicle protective properties in extreme situations (complex radiation situation), is presented a complex scientific and technical problem. In our opinion, aforementioned first of all is connected with the following:

- necessity for detailed information on spatial distribution of all the penetrating radiation components of different ammunition, on their angular and power distribution on the ground surface. For optimizing $\mathrm{RP}$ it is advisable to single out not only most hard radiation component but also to take into account spectral distribution of considered radiation according to exposure intensity. In the known literature the solution of this problem is not described in detail;

- correct selection of the appropriate radiation sources, as well as geometrical conditions for measurement. Imitation of the radiation power composition can be carried out either based on using the nuclide gamma and neutron sources and accelerators, radiation energy of which is commensurable with the energy of corresponded radiation components (individual energy groups), or nuclear reactors which allow reproducing the energy of radiation spectrum in wide band.

It should also be noted that in order to correctly assess the combat crew's ability to function, depending on the level of protection, it is of interest not only to use effective protective materials that reduce secondary gamma radiation, but also estimating the ratio of the neutron radiation dose to the gamma radiation one inside the armored object. The processes of such fields' formation inside the armored objects have not been studied enough, and the unevenness of the combat crew's irradiation created by the simul-

\footnotetext{
*Corresponding author E-mail address: imr@ukr.net
} 
taneous attenuation of several radiation components by the protective material has not been described in known literature, and requires further research.

Proceeding from the aforementioned, in this work, first in Ukraine, the results of approbation the methodology for the preproduction testing the materials developed for armored objects ${ }^{6} \mathrm{RP}$ are presented. Proposed methodology is based on determining the materials' half-value layer (HVL) to nuclear radiations, which are typical for the main situations of the radiation factor influence in modern conditions.

Moreover, taking into account the experience of liquidation accident at the Chernobyl atomic powerstation, and other atomic stations in the world with the use of army equipment, as well as probable scenarios of military conflicts with the use of modern low-power nuclear weapon, the methodology of the experimental estimating the protective properties of the developed RP materials for improving the efficiency of armored objects in a complex radiation situation, is extremely relevant.

\section{MAIN RESULTS}

To investigate the RP materials' properties, we tested the using in the laboratory the plutonium-beryl neutron source $(P u-B e)$ with a fast neutron flux of $10^{5}$ neutrons $/ \mathrm{s}$ in a solid angle of $4 \pi$. The source of $(P u-B e)$ radiation with sizes of $2 \times 3 \mathrm{~cm}$ was placed in tin cylindrical container $(22 \times 22 \mathrm{~cm})$ filed with paraffin and having cylindrical bore for the source. The scheme used for investigating the RP properties of the materials is shown in Fig.1. The main element of the scheme is the dosimeter-radiometer MKS-AT1117M (MKC-AT1117M) allowed to regis- ter the energy of neutron radiation from $0.025 \mathrm{eV}$ to $14 \mathrm{MeV}$ using intellectual detection block on the base of tube counter.

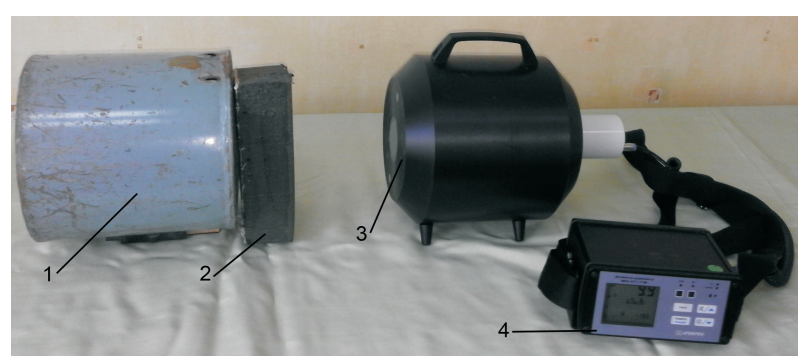

Fig.1. Scheme which have used for measurements. $1-P u-B e$ source of neutrons in container; 2 -test specimen; 3 -detection block BDKN-03; 4 - information processing block

As the test RP specimens we used layered materials described in monograph [1]: $21 \mathrm{~F} / 17 \mathrm{~F}$ which is not contain lead, but consist of $20 \%$ of polyethylene and $80 \%$ of polyisobutylene (POV-20); $22 \mathrm{~F} / 17 \mathrm{~F}$ containing $\sim 50 \%$ of lead (by mass) and $0.3 \ldots 0.5 \%$ of boron (POF20/50). Measurements of the ambient dose rate $(\mathrm{ADR})$ of neutron radiation without a test sample, with various neutron protection samples, including combinations of two samples, were carried out. To achieve an acceptable statistical uncertainty of $2.8 \ldots 3.6 \%$, the measurement time was chosen to be at least 30 minutes. Attenuation of neutron radiation ADR $K_{\text {att }}$ was calculated as the ratio of ADR without sample and with it. Results of measurements, as well as calculated by graph-analytic method HVLs for RP materials (Fig.2) are presented in Table 1.

Table 1. Results of investigating the material's properties against neutron radiation $4.5 \mathrm{MeV}$

\begin{tabular}{|c|c|c|c|c|c|}
\hline Sample & $\begin{array}{c}\text { Thickness } \\
\text { of the } \\
\text { Sample, } \\
\mathrm{cm}\end{array}$ & $\begin{array}{c}\text { ADR, } \\
\mu S v / h\end{array}$ & $\begin{array}{c}\text { Attenuation } \\
K_{a t t}\end{array}$ & $\ln K_{\text {att }}$ & $\begin{array}{c}\text { HVL, } \\
\mathrm{cm}\end{array}$ \\
\hline Without sample & & 15.4 & & & \\
\hline $1 \mathrm{a}$ & 2.7 & 12.8 & 1.193 & 0.176 & 14.2 \\
$1 \mathrm{a}+\mathrm{b} \mathrm{b}$ & 5.4 & 9.6 & 1.604 & 0.472 & \\
\hline $2 \mathrm{a}$ & 4.7 & 9.9 & 1.555 & 0.441 & 7.8 \\
\hline $\mathrm{a}+2 \mathrm{~b}$ & 9.4 & 5.8 & 2.655 & 0.976 & \\
\hline $3 \mathrm{a}$ & 2 & 13.9 & 1.107 & 0.101 & 22 \\
\hline $\mathrm{a}+3 \mathrm{~b}$ & 4 & 11.5 & 1.339 & 0.291 & \\
\hline $4 \mathrm{a}$ & 5 & 9.6 & 1.604 & 0.472 & 8.5 \\
\hline $\mathrm{a}+4 \mathrm{~b}$ & 10 & 6.0 & 2.566 & 0.942 & \\
\hline $5 \mathrm{a}$ & 6 & 9.1 & 1.623 & 0.484 & 6 \\
\hline $5 \mathrm{a}+5 \mathrm{~b}$ & 12 & 4.5 & 3.422 & 1.230 & \\
\hline $6 \mathrm{a}$ & 4 & 11.3 & 1.362 & 0.308 & 9.5 \\
$6 \mathrm{a}+6 \mathrm{~b}$ & 8 & 7.2 & 2.138 & 0.759 & \\
\hline & & & & & \\
\hline
\end{tabular}




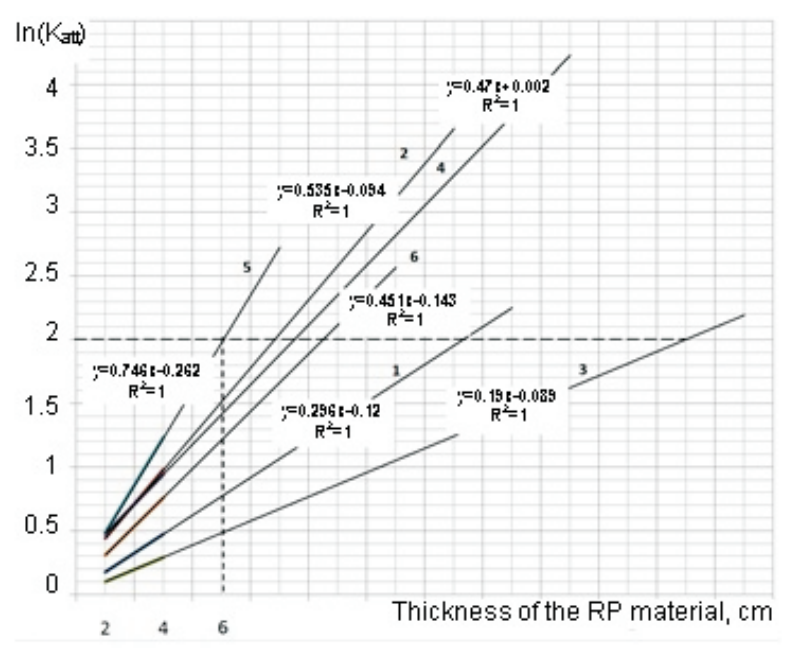

Fig.2. Determination of the HVLs for RP materials

The $5 \mathrm{a}(5 \mathrm{~b})(21 \mathrm{~F} / 17 \mathrm{~F})$ sample with a HVL of $6 \mathrm{~cm}$ has the highest efficiency to attenuate the $4.5 \mathrm{MeV}$ neutron radiation. At the same time investigating the protective properties of the considered materials under the influence of fast neutrons having energy of $14 \mathrm{MeV}$ remain to be a topical.

The analysis showed that the materials for armored objects' RP should simultaneously slow down both fast neutrons to the level of thermal neutrons, absorb neutrons (for preventing the occurrence of secondary gamma radiation), and stave off further propagation of the primary gamma radiation. Solving aforementioned tasks implies the combination of the hydrogen-containing materials ${ }^{6}$ properties possessing a high ability to slow neutrons, and heavy materials that effectively protect against the influence of gamma quanta in one sample. Than, let us consider the possible energy parameters of the gamma component.

In our work, for investigating the RP materials' properties as applied to the gamma component, we have tested the using a various labware for modeling the influence of the radiation factor characterizing various situations. Laboratory setup (on the base of linear accelerator Varian Clinac $600 C$ ) having photon energy of $6 \mathrm{MeV}$, simulating inelastic scattering and capture gamma rays in air, is presented in Fig.3.
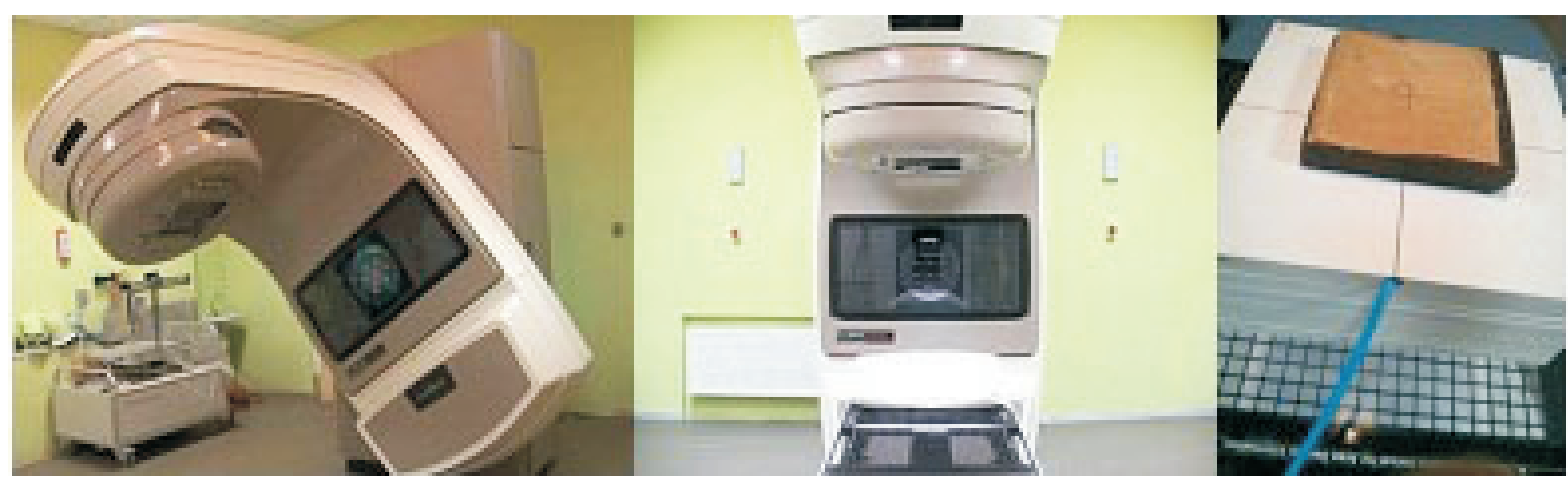

Fig.3. System based on Varian Clinac 600C and dosimetric system UNIDOSE (PTW)

The measurements were carried out using a clinical dosimeter UNIDOSE (PTW) at a distance of $100 \mathrm{~cm}$ from the linear accelerator. Reference dose made value 1.026 Gy, and exposure time was chosen $20 s$. A component of instantaneous gamma radiation from a nuclear explosion was modeled using a $\gamma$-therapeutic device ROCUS-AM, with an energy of $1.25 \mathrm{MeV}$ (reference dose 2.064cGy, exposure time $50 \mathrm{~s}$ ). Gamma radiation caused by fragments of nuclear fission was simulated using an X-ray simulator Varian Acuity, with the energy of $100 \mathrm{keV}$ (reference dose $0.346 G y$, exposure time $58 \mathrm{~s}$ ). Measurement results and calculated HVLs of RP materials for radiations with energy of $6,1.25,0.661$, and $0.1 \mathrm{MeV}$ are shown in Table 2.

Testing of the RP samples' properties as applied to radiation with an energy of $0.661 \mathrm{MeV}$ was carried out by determining the counting rate (in pulses per minute) with a tube counter (SBM-20 supply voltage $550 \mathrm{~V}$ ) and using a scaling dosimetric instrument DP-100AD with a total error of $\pm 5 \%$. The measure- ment time providing an acceptable statistical error made value $1 \mathrm{~min}$. Isotope $C s-137$ was chosen as a source of ionizing radiation. Estimating HVLs was carried out using an analogous technique used for the neutron component (see Fig.2).

The analysis of the obtained data about the properties of RP materials as applied to possible gammaray energies confirms the general regularities concerned to attenuation of photon radiation with various energies. The complex assessment of the materials ${ }^{6}$ protective properties as applied to two components of gamma-neutron radiation allows to pick out the sample having number 5 (material $21 \mathrm{~F} / 17 \mathrm{~F}$ ) with the best protective properties, both against the 4.5 $\mathrm{MeV}$ neutron component (HVL $6 \mathrm{~cm}$ ) and when exposed to photon radiation $6 ; 1.25 ; 0.661 ; 0.1 \mathrm{MeV}$ (HVLs 16,11, 10, and $3 \mathrm{~cm}$, respectively). The results of the investigating the composition of this material by the methods of X-ray-fluorescence spectral analysis and Compton scattering of X-rays using the energy-dispersive spectrometer "Sprut" SEF01 
showed the presence of lead more than $50 \%$ of the mass. To assess the nonuniformity of the irradiating the armored object combat crew, it is expedient to calculate the ratio of the HVLs for a given material to the effects of neutron and gamma radiation. For the described above energy characteristics of the radiation factor $\left(E_{n}=4.5 \mathrm{MeV}\right.$ and $\left.E_{\gamma}=6 \mathrm{MeV}\right)$, the coefficient of nonuniformity for sample $N 5$ can make value 0.37 . For the energy characteristics of $E_{n}=4.5 \mathrm{MeV}$ and $E_{\gamma}=1.25 \mathrm{MeV}$, the aforementioned coefficient for the same sample is 0.54 .

Thus, the inherent features of the protective properties of materials as applied to the components of pulsed gamma-neutron radiation of the penetrating radiation will determine the nonuniformity of irradiation of the armored object combat crew.

Table 2. Results of testing the RP material properties as applied to gamma radiation with energy $6,1.25,0.661$, and $0.1 \mathrm{MeV}$

\begin{tabular}{|c|c|c|c|c|c|c|c|c|}
\hline \multirow{4}{*}{ Sample } & \multicolumn{4}{|c|}{$\begin{array}{l}\text { Influence of penetrating radiation } \\
\text { caused by nuclear explosion }\end{array}$} & & & & \\
\hline & \multirow{2}{*}{\multicolumn{2}{|c|}{$6 \mathrm{MeV}$}} & \multicolumn{6}{|c|}{ Influence of radioactive contamination of ground } \\
\hline & & & \multicolumn{2}{|c|}{$1.25 \mathrm{MeV}(\mathrm{Co}-60)$} & \multicolumn{2}{|c|}{$0.661 \mathrm{MeV}(\mathrm{Cs}-137)$} & \multicolumn{2}{|c|}{$0.1 \mathrm{MeV}$} \\
\hline & $\begin{array}{c}\text { Doze, } \\
\text { Gy }\end{array}$ & $\mathrm{HVL}, \mathrm{cm}$ & $\begin{array}{c}\text { Doze, } \\
\text { Gy }\end{array}$ & $\mathrm{HVL}, \mathrm{cm}$ & $\begin{array}{c}\text { Counting } \\
\text { rate, } \\
\text { pulses } / \mathrm{min}\end{array}$ & HVL, cm & $\begin{array}{c}\text { Doze, } \\
\text { cGy }\end{array}$ & $\mathrm{HVL}, \mathrm{cm}$ \\
\hline $\begin{array}{l}\text { Without } \\
\text { sample }\end{array}$ & 1.026 & & 0.346 & & 1355 & & 2.064 & \\
\hline $\begin{array}{c}1 a \\
1 a+1 b\end{array}$ & $\begin{array}{l}0.91 \\
0.79\end{array}$ & 29 & $\begin{array}{l}0.29 \\
0.23\end{array}$ & 18 & $\begin{array}{c}1068 \\
742\end{array}$ & 11 & $\begin{array}{l}0.12 \\
0.10\end{array}$ & $<1$ \\
\hline $\begin{array}{c}2 a \\
2 a+2 b\end{array}$ & $\begin{array}{l}0.91 \\
0.77\end{array}$ & 25.5 & $\begin{array}{l}0.28 \\
0.22\end{array}$ & 17 & $\begin{array}{c}1087 \\
826\end{array}$ & 14 & $\begin{array}{l}1.14 \\
0.64\end{array}$ & 6.8 \\
\hline $\begin{array}{c}3 a \\
3 a+3 b\end{array}$ & $\begin{array}{l}0.99 \\
0.94\end{array}$ & 81 & $\begin{array}{l}0.32 \\
0.30\end{array}$ & 57 & $\begin{array}{l}1469 \\
1.12\end{array}$ & 43 & $\begin{array}{l}1.53 \\
1334\end{array}$ & 13 \\
\hline $\begin{array}{c}4 a \\
4 a+4 b\end{array}$ & $\begin{array}{l}0.82 \\
0.62\end{array}$ & 14.6 & $\begin{array}{l}0.25 \\
0.17\end{array}$ & 10.5 & $\begin{array}{c}1024 \\
542\end{array}$ & 7 & $\begin{array}{l}0.44 \\
0.37\end{array}$ & 7.5 \\
\hline $\begin{array}{c}5 a \\
5 a+5 b\end{array}$ & $\begin{array}{l}0.85 \\
0.66\end{array}$ & 16 & $\begin{array}{l}0.26 \\
0.18\end{array}$ & 11 & $\begin{array}{l}963 \\
662\end{array}$ & 10 & $\begin{array}{l}0.44 \\
0.17\end{array}$ & 3 \\
\hline $\begin{array}{c}6 a \\
6 a+6 b\end{array}$ & $\begin{array}{l}0.93 \\
0.82\end{array}$ & 31.5 & $\begin{array}{l}0.30 \\
0.25\end{array}$ & 23 & $\begin{array}{c}1160 \\
975\end{array}$ & 21.8 & $\begin{array}{l}1.93 \\
1.39\end{array}$ & 14 \\
\hline
\end{tabular}

\section{CONCLUSIONS}

1. The analysis of data in known literature shown that the material for armored object's RP must have universal qualities - simultaneously to slow down fast neutrons to thermal level, to absorb neutrons, and prevent further propagation of secondary gamma quanta. Aforementioned involves the combination in one material a hydrogen-containing elements that slow neutrons, and heavy components which effectively protect against the action of gamma quanta.

2. For the first time in Ukraine, the methodology for laboratory testing the materials designed for armored objects' RP has been approved by determining their HVL, which is an important characteristic of biological protection of the material for a certain energy spectrum and ionizing radiation type.

3. Taking into account the structural features of the composite materials possessing protective properties against gamma and neutron radiation, it is advisable to create databases of HVLs, for the maximum possible values of energies. Such a database will allow to optimize the design of an armored object for a variety of variants of the radiation factor influence.

\section{References}

1. V.A. Grigorian, Ye.G. Udin, I.I. Terehin, et al. Tank Protection / Ed. V.A. Grigoriana. Moscow: "Bauman Moscow State technical University", 2007, 327 p.

2. V.V.Perevezentsev. Fundamentals of Engineering Methods for calculating protection from ionizing radiation of nuclear facilities / Ed. R.S. Demeshev. Tutorial. Moscow: "Bauman Moscow State technical University", 1994, 68 p.

3. Yu.N. Tarasenko. Ionizing Methods for Dosimetry of a High-Level Ionizing Radiation. Moscow: "Technosfere", 2013, 264 p.

4. The Physics of Nuclear Explosion. Explosion Development / Russian Federation Ministry of Defense. Central Physical and Technical Institute. Moscow: "Nauka, Fizmatlit", 1997, v.1, 528 p. 


\title{
НЕКОТОРЫЕ ВОПРОСЫ МЕТОДОЛОГИИ ПРОВЕДЕНИЯ ИСПЫТАНИЙ ПРОТИВОРАДИАЦИОННОЙ ЗАЩИТЫ БРОНЕОБЪЕКТОВ
}

А. Н. Довбня, В. П. Старенъкий, И. Г. Гончаров, И. Ю. Чернявский,

\author{
А. А. Анашкин, В. А. Власенко, К. С. Овчаренко
}

Представлены результаты апробации методологии лабораторных испытаний материалов противорадиационной защиты бронеобъектов путем определения их слоя половинного ослабления к ядерным излучениям, которые характерны для основных ситуаций воздействия радиационного фактора в современных условиях.

\section{ДЕЯКІ ПИТАННЯ МЕТОДОЛОГІЇ ПРОВЕДЕННЯ ВИПРОБУВАНЬ ПРОТИРАДІАЦІЙНОГО ЗАХИСТУ БРОНЕОБ'ЄКТУ}

А. М. Довбня, В. П. Старенъжий, І. Г. Гончаров, І. Ю. Чернявсъкий, А.О. Анашкін, В.О. Власенко, К.С. Овчаренко

Представлені результати апробації методології лабораторних випробувань матеріалів протирадіаційного захисту бронеоб'єкту шляхом визначення їх шару половинного ослаблення до ядерних випромінювань, які характерні для основних ситуацій впливу радіаційного фактора у сучасних умовах. 